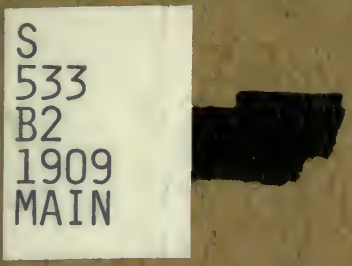

UC-NRLF 



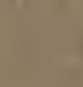

4

i

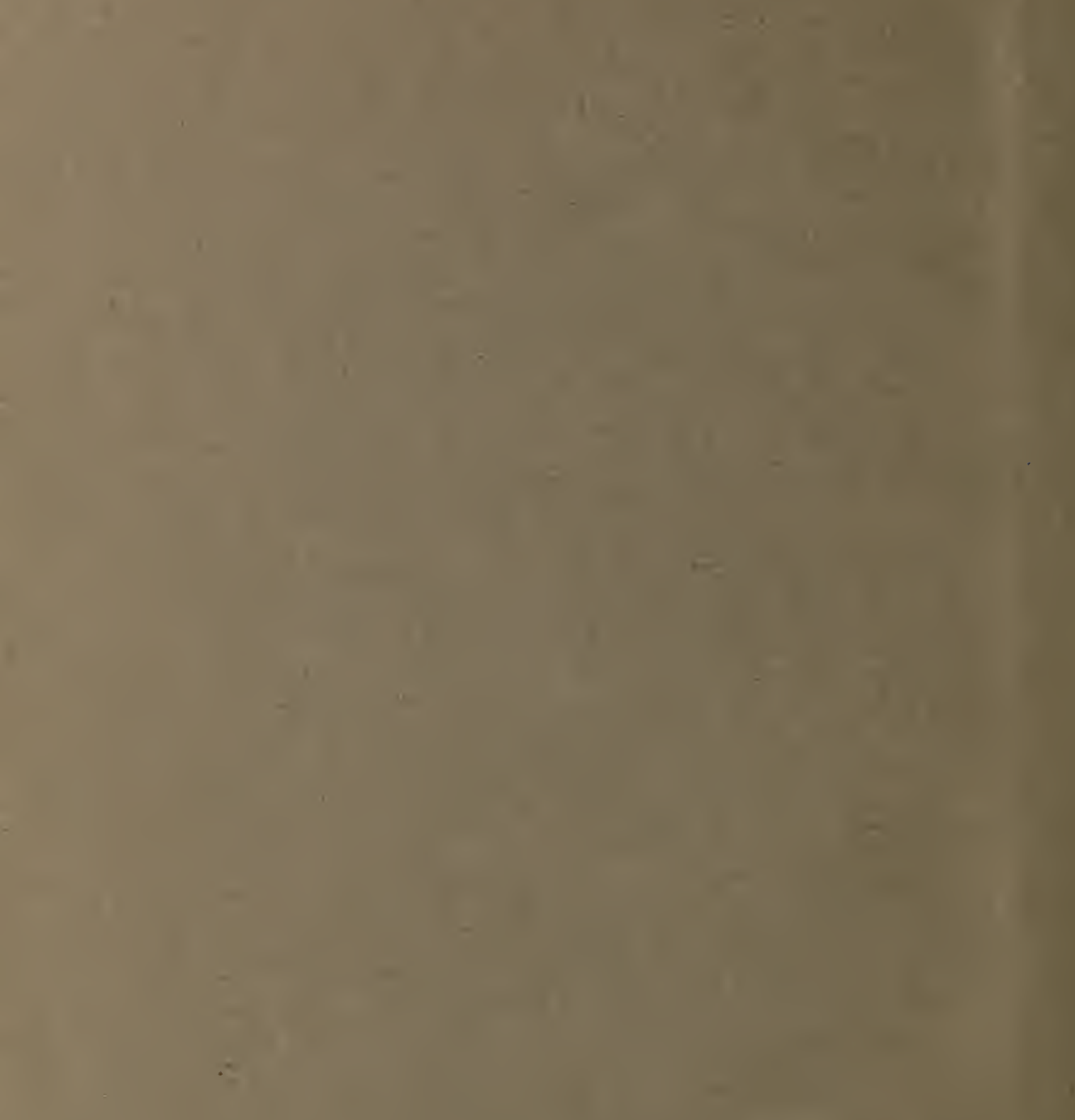

$1=$

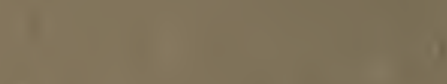

1

-
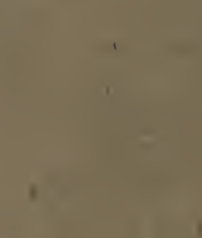

if

(

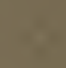

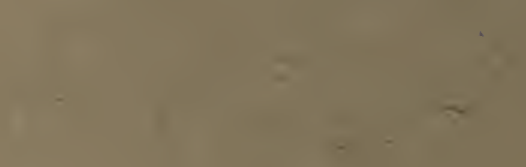

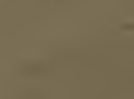


Thy trallegre af

Anritutlunte

anth the

State

BY L.H. BAILEY

AN ADDRESS DELIVERED ON THE OCCASION OF FARMERS' WEEK AT CORNELL UNIVERSITY, FEBRUARY 26, 1909 . 


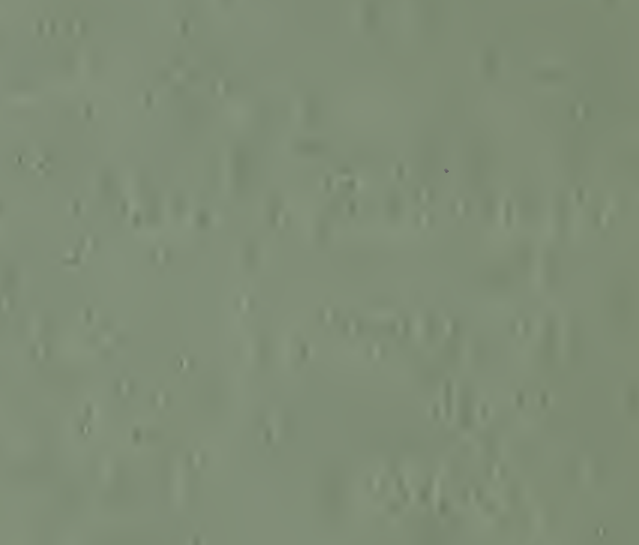

\section{LOAN STACK}

\section{GIPT}

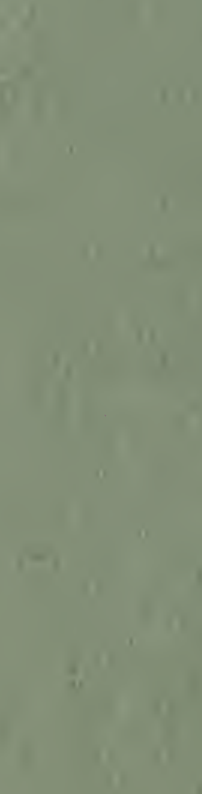


THE COLLEGE OF AGRICULTURE AND

\section{THE STATE.}

Now that we are consciously entering on a new era in the development of our country life, it is well that we take stock of the forces that are at work, and endeavor to see where they lead when put in active operation. I will first review very briefly the kinds of agencies that are now in existence, and then speak more fully of one of them. In doing this, I attempt to speak as a citizen of New York and as one interested in public questions, rather than merely as director of the College of Agriculture; for we should relate all single agencies to the good of the whole.

\section{A CAMPAIGN FOR RURAL PROGRESS.}

There is widespread interest in the welfare of the farmer and in the general condition of country life. There seems to be a general feeling that the farmer has only an unequal chance, and that his interests should be safeguarded. The handicaps that are not a necessary part of his business must be removed by government, for he does not have the power, even with the best personal farming, to take full advantage of his natural opportunities. More than this, there is demand that reconstructive movements and policies be found and set in motion that will work together to build a rural civilization worthy of the best American ideals. It is very evident that we shall soon see the inauguration of a national campaign for rural progress.

There cannot be a successful national campaign for rural progress without clear-cut state campaigns. I am not without 
a feeling of considerable responsibility for such a campaign in New York, and this leads me to give expression to my point of view on several large questions concerning the agricultural betterment of the State.

A successful campaign must come as the result of the federation or working together of all country life agencies within the State. We already have the beginnings of enough institutions and of sufficient forces to reconstruct our rural civilization if only they are well supported and if they cooperate genuinely for the general good. This cooperation can come about in such a way as not to interfere with the essential autonomy of any institution or organization, while at the same time tying them all together into one broad and common effort.

On the side of voluntary societies, we have the Patrons of Husbandry, strongly organized and progressive. There are state and district organizations expressive of certain industries or interests. The old State Agricultural Society, still in nominal existence, should now be reorganized and set to work as a general campaign association, knitting together many diverse and scattered efforts, and helping to rouse the entire people.

Many other voluntary agencies are interested in country life. Some of these are countryward extensions of town organizations, as the travelling libraries, the county work of the Young Men's Christian Association, work of the women's clubs. Churches, fraternal societies, business men's organizations, civic associations, village improvement societies and others, touch the open country at vital points. 
On the side of government, we have an active and effective State Department of Agriculture. Its function is to govern. Its duties are legal. In the prosecution of its work it will need to make scientific investigations or to have them made for it, and it will have to carry education along with much of its operation; but its work is nevertheless not research or education. It is to express the regulation and control of government in the country life affairs of the State.

The farmers' institutes, lying with the Department of Agriculture, are well organized and effective, and they reach great numbers of people in all parts of the State.

On the research side, we have a State Experiment Station at Geneva, a Federal Experiment Station at Ithaca, and also a State Veterinary College. All of them are effective. The State Experiment Station is a separate institution and is a pride to all well informed citizens. It should be allowed to devote itself to investigation. It will need to demonstrate its work on the farms of the State, and its officers should be open to the call of the people for instruction on occasion; but its real work is to strike deep for new knowledge, and public demands should not divert its attention.

The Federal Experiment Station is a part of the State College of Agriculture. It is wholly impossible for any college of agriculture to be thoroughly alive and to be great unless the research spirit is a part of it. Teachers of agricultural subjects who do not investigate are either dead or superficial, and in either case they are useless.

On the college education side, there is a State College of Agriculture and a State Veterinary College at Cornell Univer- 
sity. There is agitation for other state colleges of agriculture. There should be only one State College of Agriculture, and this should be so well supported that it can gain the primacy not only in the nation but in the world. The primacy of New York is conditioned directly on the education of its citizens. It is impossible for the State to develop several colleges of agriculture of the highest rank. We have only begun to construct one such college; if the investment in it is to be the most useful, it must be developed far beyond its present size and scope.

We now have provision for three schools of agriculture, one of which is already under good headway. More will be asked for. A pressing duty now before us is to determine what we propose to do with all special schools of agriculture that may now or hereafter be established, and to lay out a scheme. We are much in need of a system. These schools should have definite relation to the State College of Agriculture, with it becoming a part of an organized State plan. They should not be wholly isolated and separate, or established merely because the region needs a school. They should be secondary or special in grade and regional in application.

All universities on their own account and for their own best development, will in time have departments of agriculture, if they are real universities, as much as they have departments of language or of engineering. They cannot neglect any fundamental branches of learning.

The special schools of agriculture cannot meet all the needs of country people for education in terms of their daily lives. If there was one school in each of the agricultural counties of 
the State graduating 50 pupils a year, it would require nearly one hundred years to reach all the farm people of the State. A farmer has a right to ask that his son and daughter be given facilities for country life education in his home school. The State should not make it necessary for him to send them away from home for the elements of such education. It follows that all public schools should be open to education by means of agriculture on the same terms that they are open to education by other means. We have the basis for such a development in the act of 1908 for the encouraging of industrial and trade schools. I am convinced that this act marks a clear advance in industrial education in this country. This law recognizes industrial education as a part of the proper educational work of the State; and the principle that the initiative should lie with the people, and the maintenance be cooperative between the locality and the State. It provides that any public school which establishes such work and maintains it for a year shall receive $\$ 500.00$ from the State for one teacher so employed and $\$ 200.00$ for additional teachers. It limits such instruction to those who have taken the elementary school course. It provides for an advisory board to confer with the school officers in respect to the work. Now, training in agriculture is only one phase of industrial education. Training in domestic or household subjects is another phase. These principles should now be extended to the encouragement of education by means of agriculture and the domestic arts in all schools, both in town and country.

This means that the State Education Department must develop a broad policy of industrial education, with a well 
equipped department or division to administer it. This division should also have relation to the work in special schools of agriculture. Personally, I doubt the wisdom of separating the administration of agricultural education from that of other industrial education. The two lines should develop coordinately; and agricultural training should be in good part manual or "industrial."

But even all these agencies are not the only public forces that may cooperate in the development of a new rural civilization. Every public institution that owns a farm should contribute to the movement. There are prison farms, asylum farms, almshouse farms, and other land properties, comprising many thousands of acres and located in all parts of the State, that should be local teaching agents. It is not enough that public farms of this kind be merely well farmed (some of them do not even meet this requirement); they should all be demonstration areas, at least in part, to exhibit and explain to the communities the newer and better facts of agriculture. They should have some kind of relation with a supervising educational institution, and their work should be broadly organized on an educational basis.

We need to go still farther than this. There are thousands of good acres of land in the State, located directly in the centers of the best communities, that are used only one week each year and even then perhaps with little effect on the betterment of country life. These properties belong to the fairs. It is apparent that here is also an enormous property and opportunity that might be made of direct and continuing use to the people of the communities. It would be possible in many cases to 
grow experimental crops on certain parts of the fair grounds, to be standing in exhibition when the fair meets; or if not that, certainly the entire grounds could contribute to the public good 50 weeks in the year if they were carefully laid out with trees and shrubs and kept open as exhibition parks. All of them could in this way become test grounds and recreation grounds. They should be tied up to the idea of public betterment. And the fair itself should be so directed as to be an educational enterprise: there is no other reason for holding a fair. No country life institutions are so expensive for the length of time that they are in service for the public as the fairs.

I look for the time when the fairs themselves will be more continuous, with educational exhibitions given at intervals throughout the year when their effect will be greatest. All exhibits should be explained by a good teacher standing on the spot, so that the value of the effort may be increased to the utmost.

Before we can fully conserve our efforts, we must know exactly what our resources are. We are accustomed to geological surveys and to censuses to count the voters and make apportionment of voting districts. We inventory our mineral resources. But we have no accurate knowledge of the soils in the different localities, of local climate, the resources of localities in the way of woodlots and small streams, the feasibility of developing small industries in the communities (and the open country needs new industries and new interests), no good studies of local markets or of the kinds of agriculture that it would be best to encourage in any section. The central experiment station or college engages in the discovery of principles, 
but it may not be able to apply them in other parts of the State because it has no specifications of conditions in these parts. Neither has the farmer himself any adequate concept of the conditions, because no one has given him the knowledge and no one has it to give. We have now passed the stage of exploitation in the agriculture of New York. We are rapidly coming to a time when special skill must develop on our farms. This skill is, of course, conditioned on local knowledge. The greatest fundamental need in the country life of this State is a thorough-going survey in detail of our agricultural resources and conditions, as a basis on which to build a scientifically and economically sound country life. Something is being done in this direction at the State College of Agriculture, but it is pitiably small when compared with the needs. Such a survey, working out a well considered plan and continuing uninterruptedly until the entire State is covered, might properly be a part of an educational extension work. It will, of course, be expensive, but relatively no more expensive than an inventory that a merchant or a company makes of its business.

I have now enumerated the leading agencies in the State that are definitely engaged in rural work, and have indicated extensions of various lines of effort. We now need consciously to look on all these agencies as phases of one broad and general movement for the upbuilding of the rural life of the State. All of them should be federated so that they will work together toward one end. The responsible heads of all these agencies and movements should constitute a kind of consulting board to stimulate and direct the country life work of the State. The 
time has come when society must devote as much care and attention to developing rural welfare as it has given to city welfare.

All effort for rural progress should recognize the fundamental principle that the initiative of the people should be stimulated directly in the localities, and that the people should be taught to help themselves. Enterprises that originate at home have vitality, other things being equal. The reconstruction of country life must come about through the recognition and development of resident rather than of extraneous forces.

I speak for the forward look, and for the men and women who see. The trained and educated man is rapidly coming into power. This must be as true in agricultural affairs as otherwhere.

\section{THE RELATION OF THE COLLEGE OF AGRICULTURE TO THE PROBLEM}

All the agencies and institutions that I have mentioned, and also many others, are necessary to the working out of the great national problem of rural life. All of them could be quickened and extended with good results. At the present time, I desire to direct your attention to the possibilities of one of these series of institutions-the College of Agriculture.

The leadership in the forward movement must, of course, be educational. It must dispense information and formulate it into knowledge, and rouse the people by putting before them better methods and higher purposes. The natural centers of free and spontaneous leadership in the various states are the 
colleges of agriculture, that draw their support conjointly from the State and the nation. If any of these colleges are not taking the leadership, they are not meeting their opportunity or carrying their natural responsibility. It is said that the government of some of them is not such as to attract the best men or to encourage them to greatest action. If a due sense of their obligation to society were imposed on them, it would at once raise them out of political control and pedagogical bondage. For years, these colleges have been praying for funds and freedom to do their work. The obligation rests on the people to demand that these colleges do the work that is theirs to do.

Coming now to New York, we find a College of Agriculture that is wholly outside of partisan control. It can give all its energies to educational work. I propose to explain to you what I conceive this educational work to be.

This College is a part of Cornell University, its policies being determined by the President of the University and the Board of Trustees; and its work thereby is related broadly to general educational development.

Let me say, at the beginning, that this College of Agriculture represents the State. Its purpose is to aid in developing the resources of the State, in its materials, its affairs, and its people. Its special field is the open country, by which we mean that part of our civilization and welfare that lies chiefly outside the cities. Its primary purpose is to develop those industries and interests that rest on the producing power of the land. Its work is constructive. 
Scope of a

college of agriculture.

While the College of Agriculture is concerned directly with increasing the producing power of land, its activities cannot be limited narrowly to this field. It must stand broadly for rural civilization. It must include within its activities such a range of subjects as will enable it to develop an entire philosophy or scheme of country life.

On the production side, a first-rate college of agriculture deals with all crops, the means of growing them and handling them and of caring for them in health and disease; and with all domesticated or controlled animals, the means of rearing them and handling them and of caring for them in health and disease. The crops include all plants reared by man from the soil, or controlled and used by him, as all grains, all forage, all fibers, all timbers and forests, all fruits and garden vegetables and flowers, and whatever else in the vegetable kingdom he produces or improves by foresight and care to supply the wants of his fellowmen. The animals include all tamed mammals and birds, all fish that are reared and bred, the bees, domestic pets, and all others that contribute food, fur, pelts, and products for the maintenance and comfort of man.

All civilization develops out of industries and occupations; and so it comes that agriculture is properly a civilization rather than a congeries of crafts. The colleges of agriculture represent this civilization, in its material, business and human relations. Therefore, they are not class institutions, representing merely trades and occupations. The task before the colleges of agriculture is nothing less than to direct and to aid in develop- 
ing the entire rural civilization; and this task places them within the realm of statesmanship.

The colleges of agriculture have three proper lines of work: the regular or ordinary teaching; the discovery of truth, or research; the extending of their work to all the people. I mention these in the order in which they have been recognized. These colleges are founded on the Land Grant Act of 1862 ; the experiment station side was added in 1887 ; the extension side is not yet regularly recognized by Congress, although it soon must be, but is it established in most of the colleges to some degree and has been in some cases, as in New York, recognized by state appropriations. All these are essential parts of any living college of agriculture: discovery of fact; teaching it to students; taking it to all the people.

\section{The Regular College Work.}

New York State leads all the states in the extent and importance of its agriculture when measured both by the proceeds and by the variety of the products. Its agriculture is more difficult than that of many of the states that lead it in popular estimation. The extent of special knowledge about every crop and every kind of animal has now come to be so great, and so many persons are asking definite questions and deserve such explicit and careful replies, that teachers are becoming more and more cautious about giving advice. This means a greater degree of specialization and consequently many more teachers, each teacher teaching only that which he personally knows. 
The regular college work comprises not only teaching but search for new truth. All progress and increased efficiency is conditioned on knowledge of the facts and laws of nature. It is impossible to have a good college of agriculture without careful research work as its basis. Therefore, every effort must be made to secure able investigators and to enable them to pursue their work with perfect freedom, and not to hold them rigidly merely to problems of immediately so-called practical importance.

\section{Crops and live-stock.}

There are more than 80 persons on the staff of this College of Agriculture, yet there are not half enough to make it possible to answer anywhere near all the questions that are asked by the practical farmers in attendance here this week. There should be specialists in cereals, potatoes, hay and forage, the different kinds of fruits, the different kinds of vegetables, the different kinds of flower crops, forest crops, nursery crops, in cattle, sheep, horses and mules, swine, bees, fish and other aquatic animals, all the different kinds of poultry. New varieties and types of plants must be bred to adapt our crops exactly to our special conditions. And all these specialties must rest on the fundamental sciences of physiology, physics, chemistry, meteorology, biology, and the others, all of which must also be represented by strong teachers. Every precaution must be taken to develop these fundamental sciences coordinately with the application work on the farms.

Every teacher must have land, rooms and equipment. Persons studying poultry are as much entitled to class-rooms 
and laboratories as those studying chemistry or philosophy; and a poultry student occupies as much room as any other student, and needs as good a seat to sit on and as good a microscope to look through.

\section{Particular examples.}

Nearly all the most important field crops of the State have been neglected, and no crops have received the study that is required to enable the grower to get the most from them. The potato crop is more important, in value, than the apple or than poultry. Corn is more important, in value in New York, than apples or sheep. Yet apples and poultry and sheep are not minor interests, but represent great values. There is always a tendency to study local crops and specialties, to the relative exclusion of the great underlying staples. In order that you may understand how little really has been done with staple industries, I cite hay and pasture, forests, and fish as examples.

Grass is the fundamental crop of this State. Of the I 5,599,986 acres in farms in New York, $5,1_{54,96}$ are in hay and forage, and $4,366,683$ acres are in all other crops. The remainder, $6,078,338$, is probably mostly in pasture. The farm land is, therefore, approximately

One-third in hay

One-third in pasture

One-third in all other crops.

The value of the grass crop is no less striking. The hay crop is worth as much as all the dairy products. It is worth nearly as much as all other crops combined. It is worth over five times as much as all the orchard products. We have no esti- 
mate of the values of pastures, but the hay and pasture crops are undoubtedly worth more than all the animals and animal products sold, and are worth more than all the other plants or plant products. They constitute considerably over one-third of the total products of New York farms. The value of hay has increased 66 per cent. since these figures were taken by the last census. In spite of these facts, the State has done practically nothing to aid in grass production. The amount of money that has been spent by the State to encourage some of the minor interests would have brought much greater returns if expended on our fundamental crop. There is as much opportunity for improvement in grass production as there is in fruit production. We should have at least one man who will give his entire time to a study of the hay question. He should conduct large numbers of co-operative experiments and should study our great hay crop from seed sowing to marketing. This is largely an extension enterprise but will, at the same time, result in much increased knowledge. We should have one man who will devote his entire time to the pasture problem. He should make a study of present pasture conditions throughout the State and should try the new kinds of grasses, as brome grass, in the different regions. There should be co-operative pasture experiments in which different mixtures and treatments are used and in which the results are measured by pasturing each area separately. Both of these lines of work would soon require a larger number of persons working on them, if the situation were met adequately.

There is no point in developing meadows and pastures unless we produce live stock to consume the product. In fact, the 
possibility of developing them depends to a great extent on the animals themselves. We are making progress with the dairy cow and with special kinds of animals; but I am convinced that we need to give new and greater attention to the general live-stock interest of the State, not only for the profit that may come from the stock itself, but also that we may develop better forms of diversified agriculture and maintain the fertility of our lands. As our fundamental crop is by nature grass, so must a highly developed animal husbandry be a necessary part of our agriculture. We must develop such crops and such plans of farm management as will enable us to feed our live-stock profitably. We have lost our supremacy in sheep. In $185^{\circ}$, there were about three and a half million sheep in New York. There has been a continuing and marked decline in the number, until in I900 we had less than one million; and yet we have all the natural conditions for a good sheep husbandry. The rearing of horses should be an important part of our farm business. We need more swine and more beef cattle. Not only this, but our poultry and dairy interests need increased attention. It must not be forgotten that in developing these great agricultural interests, we are also providing the very best means of educating students through the knowledge that we gain; and to educate young men and women by means of the common affairs of country life, is the primary object of this College of Agriculture.

Another great cropping interest that needs to be developed is the forests. Timber is as much a crop as corn or potatoes. It should be planted, cared for, and harvested. It is one of the greatest crops of this State. In the last census year, 
New York led all the states in the value of farm-forest products. The value was"about $7^{1} / 2$ million dollars' worth. About onethird of the State is in timber or wood-lots. Very little of this vast area is yielding anywhere near what it should. The ordinary forest is half waste. Nearly every large farm in most parts of the State has its woodlot, as it has its meadow, its pasture or its wheat field. Farmers may receive instruction about all their crops with the single exception of the woods crop. We ought to raise the larger part of our farm lumber and timber, as we should raise our own meat and butter and fruit and silage. It is all the more remarkable that the farm forests do not receive attention since they exert great influence in maintaining the sources and controlling the flow of streams, in preventing floods, in protecting game, and in making the country attractive. Their value extends far beyond the particular farm on which they stand. The proper destiny of much of the so-called abandoned farm land is to grow forests. Much of our remote and agriculturally unprofitable land should be owned by townships and counties (or by the State), and be used for forest. In time these lands should return a fair revenue to the communities. New York is by nature a tree-growing State. We should preserve these resources and teach our people how to increase them.

We think of farming as a dry-land business. It is a fact, however, that an acre of water may be made to yield more food than an acre of land. There are tens of thousands of acres of fresh water in New York State, and great expanse of salt water. In time we shall cultivate these fresh waters and the sea shores. The man who owns a lake or pond, or has the 
use of one, will in the future find it to be valuable agricultural property. We shall breed domestic varieties of fish as we do of pigs or poultry. Some of the European peoples are doing this now. At present we are stocking our lakes and streams with game fish for sportsmen. As competition increases, however, we must stock the ponds in the same spirit as we stock our pastures. We have passed the hunting stage with cattle and sheep. We shall then come to a scientific development and utilization of water fields. We shall not allow people to poison and pollute the ponds and lakes any more than the wheat fields. After we stock the ponds and streams with young fish, we shall provide ways whereby they may live and thrive, the same as we till and fertilize corn or any other crop. This means the development of natural fish forage and also such control as will maintain the balance of nature. We know practically nothing about fish forage and the means of growing it in streams and lakes. We have established experiment stations for land crops, but not for water crops. The first scientific study of these questions in this country from an agricultural point of view, has now been established in this College of Agriculture (the professorship supplied from other than State funds). We have had to invent a name. We call it the Department of Limnology. The headquarters are in this building, but a laboratory and breeding station is in the marshes at the head of the lake. There is now on foot a movement to impound waters in the Adirondack region. Whenever waters are impounded, the possibilities of making them breeding grounds for food fish should also be considered. It is probable that other aquatic animals than fish, or semi-aquatic ones, will be regularly grown 
under control in time; and it is not too much to expect that we may find new uses for much of our marsh land. There are many aquatic plants that are of value. But all I aim to do at present is to challenge your attention to an undeveloped line of agricultural effort.

\section{Household subjects.}

But the kinds of crops and of animals and the fundamental subjects in sciences and language and arts, do not cover all the teacherships that a good college of agriculture must have. I must call your attention to the fact that while the home is the center or pivot of our civilization, it is the last thing to be taught in schools. We have worked out better plans for feeding and rearing pigs and cattle than for humans. The federal government may investigate diseases of sheep in the various states, but it may not investigate diseases of men and women. The whole range of household subjects must be taught, and if so, there must be specialists in food, sanitation, nursing, house building, house furnishing, and similar subjects; and all these departments of knowledge must be housed, equipped and maintained. It is probably more important that we now attack the home side of country life than any other phase of the work.

\section{The mechanical side.}

All the manufacture phases of country life must be developed. The dairy department of this College represents one of these phases. All the subjects relating to the canning, drying and preserving of fruits are practically untouched in the colleges, 
and yet nothing is more important to the development of our fruit and vegetable-gardening interests. The curing of meats and home manufacture of animal products must be taught; and also the whole great question of refrigeration and storage.

The whole subject of mechanical power and of the best use of machinery must be developed on the American farm. With all our knack for invention, we are not the foremost people in the application of small power to farm work and housework. The necessity of economizing human labor must itself force the use of gasoline and other engines, small water power, electrical power, and others, on thousands and millions of farms; and the use of such machines will set new ideals into the minds of men. With the development of long-distance transmission of electric energy, it will be increasingly more possible for such power to be diverted to farm uses; and yet we do not seem to be giving any attention to this subject, although the development is coming in Germany and other countries. Every good farm must in time have its own power; but we must first train up a race of mechanic-minded farmers. Even the common farm machinery is not usually understood by those who use it, nor, with all our invention of machines for the easier and more wholesale farm practices, have we yet developed farm machinery to anywhere near its possible extent of perfection or necessity. The burden of household labor is to be solved in part by better mechanical contrivances. The mid-western states are realizing the importance of developing the machinery-sense in the young farmer, but in New York we are distantly behind. Colleges of mechanic arts cannot be asked to develop this subject, for they have their legitimate 
professional work; and, moreover, the problems of farm mechanics are largely agricultural. The subject must be developed as part of a constructive philosophy of rural life.

\section{Engineering questions.}

Similar remarks may be made of some of the applications of engineering. The lay-out of the farm, the running of levels, drainage, irrigation, the making of farm bridges, the construction of farm roads and of highways, and the development of a rational point of view on engineering problems as they affect country life, are all of the first importance. The engineer is to exert tremendous influence on the development of our rural civilization, playing a part that we little realize today. The whole system of highways and byways will surely be evolved, as one part of the development of our natural resources. This evolution must depend in good part on the attitude of the farming people. I am afraid that we are in danger of making the mistake of developing our highways only from transported material, as we have continued to be in error in depending for fertility on material mined in some other part of the globe. The best philosophy of farm life is to develop the business directly from native home resources; this must be equally true of roads, at least of the greater number of them. What we now very much need is knowledge of how to build serviceable highways with the dirt and other material of the neighborhood. There should be at this College of Agriculture a good-roads school. A course of at least three months should be offered to all highway commissioners and overseers in the State, in order that they may be able to carry out the instructions of engi- 
neers and properly to care for the roads under their charge; and the laws should be so framed as to allow any township to send such officer to the school. The instruction should include not only simple road-making questions, but such economic and general questions as the relation of highways to local taxation and agricultural affairs, the proper distribution of highway service, and the general development of the community and State. The State cannot afford to expend millions of dollars for highways until the local officers are properly trained for their duties. The whole subject is broadly an agricultural question, and the instruction should be sympathetically tied to other agricultural instruction.

\section{Farm architecture.}

The point of view on the proper kinds of buildings for the rural country must be radically changed before such buildings can be perfectly adapted to their uses or country life be wholly attractive. We are so accustomed to our buildings, both in country and city, that we do not think to challenge them; and yet there are relatively very few buildings in the world that are either good to look at or are well adapted to their ends. All architecture is either good or bad, whether the building costs five dollars or five millions: it must have good proportions and exactly meet the needs for which it is constructed. Certain dry-goods boxes appeal to us in their attractive shape, yet we forget that shape and proportion are the first considerations in the good looks of buildings. All the sanitary waterworks and other conveniences of modern residences must come into country districts, and this will call for new plans of 
buildings. How to build a house to save steps, to cause it to be sanitary and cheerful, to insure good construction, to make it comfortable and durable, are questions of careful planning; and the more we build by merely copying other buildings or depending on the wit of the carpenter, the longer will we continue to be held by tradition. The silent and continuing influence of the building in which it lives, has a powerful effect on the child. The proper building of barns, dairies, stables, creameries, poultry houses and all the other constructions of the farm, must now receive expert attention. The experts cannot be practicing architects, because the fees in farm building are insufficient; the regular architects do not study these questions. The experts must come from the colleges of agriculture or other public institutions. Within a generation practically all the farm buildings in New York should be rebuilt. Who is going to direct the work?

The farms of this College of Agriculture should have a number of model farm houses of different cost, with the grounds properly laid out and planted.

\section{The landscape.}

Akin to all this is the development of the landscape features of the open country, - the proper subdivision and lay-out of farms, the placing of buildings for best effect, the plan and planting of all yards and roadsides and school grounds and church grounds, the preservation and improvement of scenery. All this is necessary to make the country as attractive and as satisfying as the city. It is also an economic question. Plans are already underway in a few of the states for the 
parking of the entire area of the commonwealth in such a way as to make all parts accessible, to develop what is best in every part, to preserve all good natural features. This idea will extend to every part of the country in time, developing local patriotism and increasing the values of property. Scenery as well as soil can be capitalized, and made to yield a profit. The increase in values of farm property in this State is coming largely as a result of good roads and general improvement, rather than merely from better farming. The leadership for this general improvement work should be expected to come from this College of Agriculture.

\section{Farm management.}

All the technical special work should be tied together by a department of farm management, which develops in the students' mind a business philosophy or system. There is great need of information on the planning and lay-out of farms. Even in so simple a matter as the arrangement of fields, there is need for much study and experiment. The whole cropping scheme on New York farms should be overhauled. Special investigations should be made of farming systems for the hill lands, now that the older farming is being driven from these regions. The entire subject of farm accounting must be attacked in a new way. The ordinary bookkeeping will not apply. In visiting practically every farmer in one. of the counties of the State, we did not find one man who knew how much it cost him to produce milk or to raise any of his crops. 
The human problems.

We must also study the people themselves and the affairs whereby they live. These are economic and social questions, concerned with the whole problem of how the people organize their lives and their business. On the economics side are the great questions of taxation, distribution of products, marketing, business organization, and the like. The whole relation of the man and woman to the community in respect to social intercourse, schools, churches, societies, the broad influence of telephones and roads and machinery on rural life, the social results of immigration, the scheme of rural government, the policies of cooperation in a thousand ways, and, in short, the structure of rural society, constitute a special field of inquiry. For cities many of these questions have been studied with care, and measures of relief have been set on foot when they were found to be needed; but in the country these great human problems are practically untouched. There is as much need of an agricultural application of economic and social questions as there is need of an agricultural application of chemistry; in fact, there is greater need of it, for at the bottom all civilization is but a complex of these human questions. This College of Agriculture has a modest beginning in this essential field, but the work is wholly inadequate to the needs of the State.

\section{Training teachers.}

The public schools must teach persons how to live. This will call for a complete change in their methods and their point of view. New teachers must be trained. We can not expect any very great progress by merely adding new work to old 
methods or asking present teachers to take on a new philosophy of service. The whole school system must be redirected and reconstructed from the bottom up. This means that in rural districts, pupils shall be educated by means of rural subjects as well as by other means. Of course, all this new effort will come slowly (we could not assimilate it in any other way), but we must prepare for it, nevertheless. This College of Agriculture should be enabled to expand its little normal department so that it can contribute greatly to prepare teachers to handle the agricultural work in the public schools of New York. There is no greater work now before this College of Agriculture than this.

\section{The needs.}

I have now suggested very briefly some of the larger groups of subjects that this College of Agriculture must be prepared to investigate and to teach if it is to be the kind of college that you all want it to be. It will be seen how vastly has the outlook of the colleges of agriculture enlarged within recent years. They are not at all what they were ten years ago, even five years ago; and yet most of the criticisms of them that I still hear are founded on the memories of years now past. For forty years these colleges have been finding themselves and trying to convince the public they are designed to serve, what the field before them really is. If they have not met all expectations, it is largely because their facilities have been al-

Note.-I have stated my own convictions as to the means of training such teachers in a pamphlet "On the training of persons to teach agriculture in the public schools", published by the U. S. Bureau of Education, Washington, I 908 . 
most trivial as compared with the work they have been expected to do. Whether they will in the future accomplish all that is expected of them will depend as much on the people as on the professors; in fact, in the end the people have control.

These colleges are expensive. They are the most expensive of all colleges, because they must do so very many things, be prepared to give advice on every conceivable subject of country life, have so much land, so many different kinds of live-stock, such extensive orchards and grounds, reach so many special industries, and give such personal and practical instruction to their students. This is exactly the opposite of the prevailing notion, at least until very recently. There are still some persons who think that a college of agriculture should be practically self-supporting, because it engages in farming; yet I usually find that such persons have difficulty enough in making a farm pay as a farm, without asking it to support teaching and experiments in the bargain. It will be some years yet before this or any other college of agriculture catches up with its problem; we are in the beginning period of the modern development, and how rapidly and how far these colleges develop will determine to a great extent how rapidly and effectively rural life shall be reconstructed.

\section{The Outside or Extension Work.}

What I have thus far said has referred mostly to the inside or so-called academic work of the College of Agriculture. I now call your attention to the outside or extension work. I am not doing this to seem to make the subject big, but be- 
cause I am under obligation to you to state what I see. We must fairly face the work that is before us.

By extension work, I mean all kinds of teaching with the people at their homes and on the farms. The three great phases or sides of agricultural college work, as I have said, are the experiment or research, the regular college teaching, and the outside teaching. The college teaching must be founded directly on the knowledge gained in research, and the extension work must be founded on both. Colleges of agriculture are the only educational institutions that are charged with the double responsibility of teaching the students who come to them and of developing the business in which these students and their parents engage.

This College of Agriculture cannot serve the state as it is capable of doing without engaging in many kinds of extension work. It ought to serve farmers who cannot go to college, or who do not know what a college is. The College must be taken to the people. All State colleges should become a real part of the machinery of society (or the State), participating directly in all, work for the good of the people, so far as such work comes within the range of their subject-matter. They become, thereby, a real expression of the needs and the ideals of the people. 
Kinds of

extension work.

Extension work in agriculture includes all effective personal acquaintanceship with the farmers of the State; all inspection of farms that is not legal and police in character; the giving of advice by correspondence; publication of an educational nature; all cooperation with societies and organizations; advisory and cooperative work with schools; the organizing of boys' and girls' clubs in schools and country districts; the conducting of reading-courses for farmers, farmers' wives and rural school teachers; experiments or demonstrations on farms; running of "farm trains;" holding of "farmers' weeks" and other conventions; lectures, itinerant schools, and the like; and all species of helpfulness and advice to the people on the land. The extension department of a college of agriculture should be a means of arousing the country people, and then of helping and guiding them. It will be effective in proportion as it works harmoniously and full-heartedly with all other agencies for rural progress.

\section{Lectures}

and travelling teachers.

The best vehicle for much of the extension work is a public iecture service, and this service will naturally develop with such work. This raises the question as to the proper place for farmers' institute service. Historically, the institutes have developed in different ways, some of them issuing from colleges of agriculture, some of them from state departments of agriculture, and some of them from a separate or special 
organization. If they were to be developed anew today, they would naturally issue from the colleges of agriculture, if the colleges in the different states were capable of handling them, because they are educational agencies and because the extension enterprise of the college must on its own account develop similar work. There is a popular impression that farmers' institutes will soon have served their purpose and will naturally discontinue. I doubt whether this is true. It certainly will not be true when they constitute part of a well organized extension-teaching scheme. The nature of their work will change from year to year, as any other living work changes; but it will always be necessary to instruct the farm people at their homes. It will be increasingly necessary to substitute demonstration and laboratory work for much of the lecturing. We must develop a new type of institute man, unlike the college professor on the one hand and the so-called practical farmer on the other. These men must be trained for this kind of public work, as carefully as other men are trained to be chemists or engineers. They should live for at least part of the year on the land, and they should also be connected with an institution that can keep them in touch with the best and latest information. In other words, they should be farmers as well as students, and students as well as farmers. The regular college or experiment station specialist will be called on here and there when expert knowledge of a particular kind is wanted, but his main effort should not be diverted from his regular work. The institute teacher, in all the states, will then be chosen with the same care that a college or experiment station chooses the members of its staff; his teaching will be as 
carefully watched and supervised, and he will receive as good pay. Under these conditions, the institutes will endure.

Taking stock

of country life.

The best extension work must attack the fundamental problems of country life, as well as merely the betterment problems. We must have a thorough-going study of the exact natural resources and conditions of all agricultural regions, as I have already explained (page 7). Such a study or survey must be very carefully planned and organized, and on such a basis that it may proceed regularly year after year until the entire state is discovered. Within this scheme should be included, as component parts, all soil surveys, orchard surveys, live-stock and dairy surveys, and whatever other systematic studies are made of the products, industries, people and institutions of the localities. For some years we have been engaged in an agricultural survey of Tompkins county, and in more partial surveys of other counties; these censuses afford good experience on which to found a complete survey of the State.

The Commission on Country Life has recommended survey work of the above character and extension work by the colleges of agriculture as two of the fundamental movements now required for the permanent development of rural life.

\section{Teaching on farms.}

I regard certain kinds of demonstration work on farms as of the greatest teaching value, if it is conducted by a good 
teacher. Our educational methods have been greatly improved by the introduction of the laboratory, whereby a student is set at work with a personal problem. The laboratory work may be the actual observation and study of a plant disease or an animal disease, of a rock, a soil, a physical phenomenon, the making of a school-garden, the making of cheese or butter, the feeding of a cow or horse, the incubating of eggs, work in an orchard or greenhouse, the planning of grounds or buildings, or whatever other actual work that it is worth while to do under the guidance of a teacher. Now, a man's farm is his laboratory. No one may direct him how to manage his farm; but a good teacher coming to his place may set him into new lines of thinking and put him in the way of helping himself. In a moment of my younger enthusiasm I once wrote that every farm in the State should be visited at least once each year by a good teacher. My calmer judgment leads me to expand the statement to the effect that every farm in the State should be considered as one part in an underlying fabric of human evolution, and that in the interest of society every farm should ultimately be known to someone who represents society, to the end that that farm may be made a more effective unit in the great plan.

Whenever an agricultural problem is worked out in the laboratory, its application should be at once widely demonstrated in the field under actual farm or garden conditions, and this of itself will require a large corps of high-class men. This will relieve the continuing demand for local experiment stations. Field laboratories will need to be established in the localities until the application of the problem to the locality is 
worked out. I am inclined to think that some of the aid rendered to special communities and interests, however, should be paid for directly by the communities themselves so far as the services of the expert or agent are concerned.

Teaching on farms I consider, therefore, to be fundamental to rural progress. Whatever we have thus far done in this kind of teaching - and we really have done much-is the merest beginning of what the State would profit by. This kind of teaching will be most satisfactorily effective when it can follow or be made a part of the survey or inventory work that I have been projecting.

\section{Local leaders.}

If a college of agriculture is to extend itself over the State, it will need to have local agents or representatives, who will keep the institution informed of the needs of the locality and be prepared to give advice and to look out for the agricultural welfare of the people. This agent should be to agricultural interests what the teacher is to educational interests and the pastor to religious interests. This type of local leader has already been set to work in Canada, and we are making a beginning in an experimental way in New York.

\section{The Work is Upon us.}

All this may seem to be far away to the philosopher and the dreamer, but the plain people are ready. If you could know the requests and the demands that come to this College from the folks on the farms and in the rural schools, you would realize that all these problems are on us at this moment, and that 
something worth while must be done to solve them. This institution can little more than touch the spontaneous demands of the people, let alone starting new plans. We are pressed to the utmost merely to keep up. Every one of the twenty departments of this College must have greatly increased facilities if the country life interests of the State are served as much as they need to be served.

We are conducting reading-courses with less than 16,000 farmers and farmers' wives in New York, yet there are a half million such in the State. We are reaching at this moment less than 7,000 teachers, but there are 40,000 school teachers in the State and hundreds are being prepared every year. We are reaching 65,000 children this year, out of $1 \frac{1}{2}$ million in the elementary and high schools of the State. We are conducting demonstration or test work on some 300 farms out of the 227,000 in the State. We are teaching one student for about every 500 farms. In this College of Agriculture, large as it has grown to be, we yet have less than one student to each rural township in the state. There are probably more farm boys and girls in any one agricultural county in the State than are now in this College of Agriculture. All this is in spite of the fact that the number of students is increasing so rapidly that we cannot properly keep up with the work. The value of farm property in New York in the last census year was $\$ 1,069,723,895$. The money appropriated for maintenance of college education in agriculture is about one sixty-sixth of one per cent. of this valuation.

Persons constantly express surprise that these buildings are packed to their utmost even when they are little more than 
completed. It is a fact that they are packed, however, and that we ought to accept no more students with the present facilities. This is only a demonstration that the people are ready. Not all the farm youth, of course, will want a college education, but enough will want it to warrant the doubling of the present plant of this College of Agriculture at once.

The mere increase in numbers of students, (there are now more than 800) makes demands on teachers and equipment that very few persons understand. It is not merely a question of finding a place in which students may sit, but desks for laboratory work, microscopes and other special apparatus, animals, library facilities, and a hundred accessories that the layman knows not of. Modern agricultural education has become a very much specialized business, and each student works with the objects and things themselves and receives careful personal help from his teacher.

The special agricultural schools and the agricultural work in the public schools, and the work of this College of Agriculture should all be organized into a system or plan, the development of which should proceed in an orderly way and as rapidly as the needs of the State demand.

I have now sketched very hastily some of the activities that properly belong to a college of agriculture. I have wanted to present this outline in the formative stage of the College, in order that the people may discuss the institution at their leisure and be able to make up their minds what kind of College they want and how far they desire to see it developed. 
The legislatures will do whatever you earnestly ask, within reason, so far as there are sufficient funds for it.

The staff of this college is engaged with great activity in unselfish work for the people of the state. It is because they are alive that the work is growing. They all desire to devote themselves to this work so long as they are connected with the institution. . It is our duty, as servants of the State, to say what things are needed to make the institution what it should be, as we see the field. We should not withhold the knowledge of anything that is needed. The support of the College has been liberal. We shall always work whole-heartedly with what we have. We are interested in the institution only as it is an organ for serving the state. Having stated the outlines of the most serviceable type of college of agriculture, the problem of how far it shall be developed must rest with the people themselves.

The commercial and social isolation of the farm is passing. The country town is no longer the market and the center of interest. The farmer is rapidly becoming a citizen of the world. All his problems must have a larger treatment than they have ever had before. 




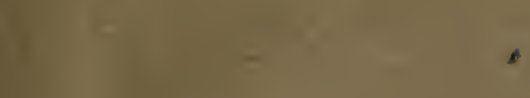

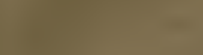

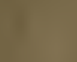

(19.10)

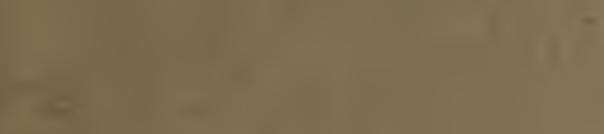

$-$

1

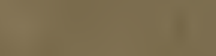

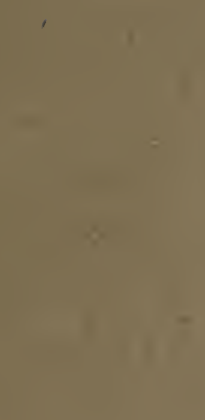

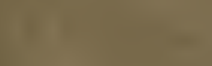
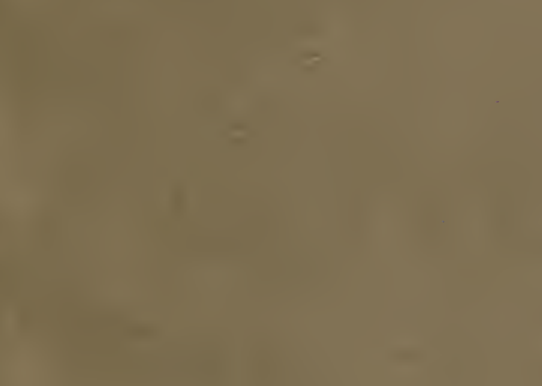

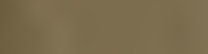
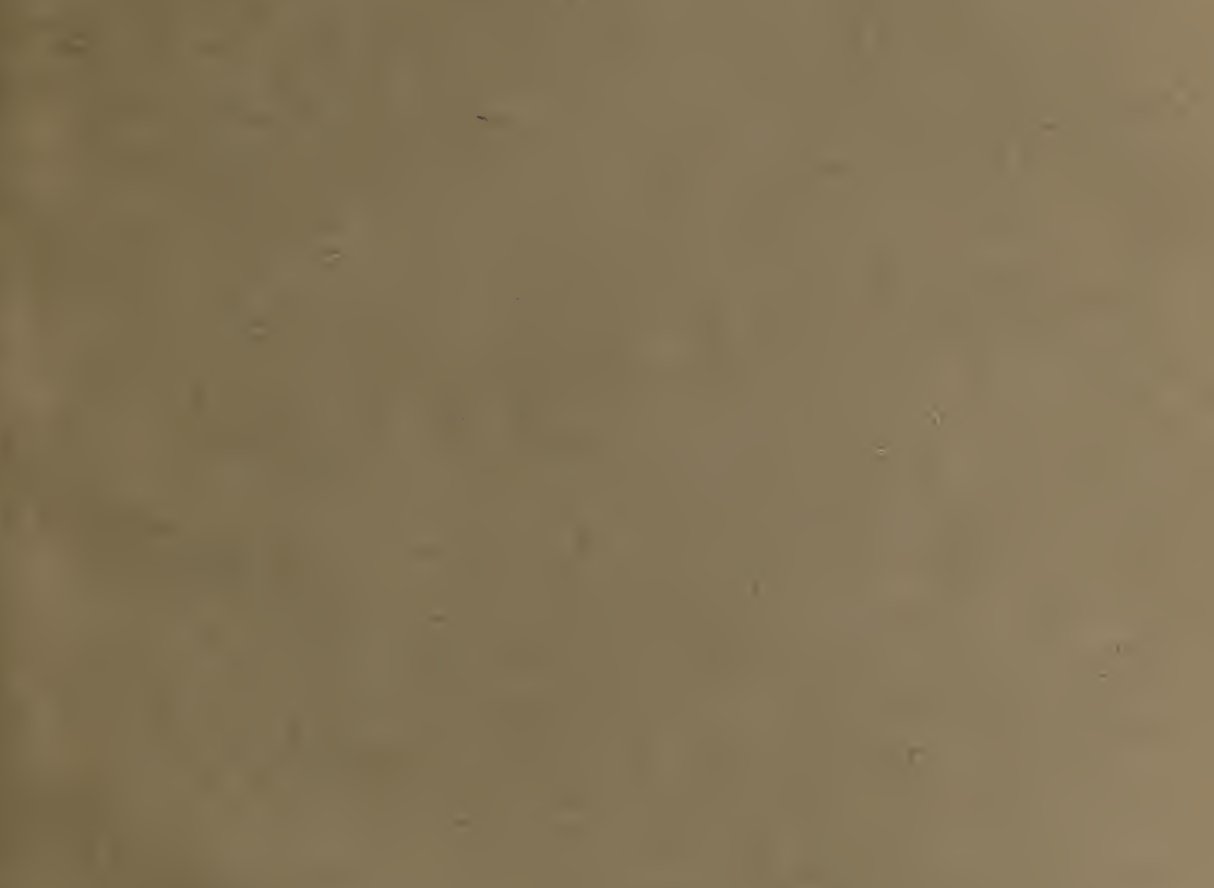

$+$

$1+$

$=$

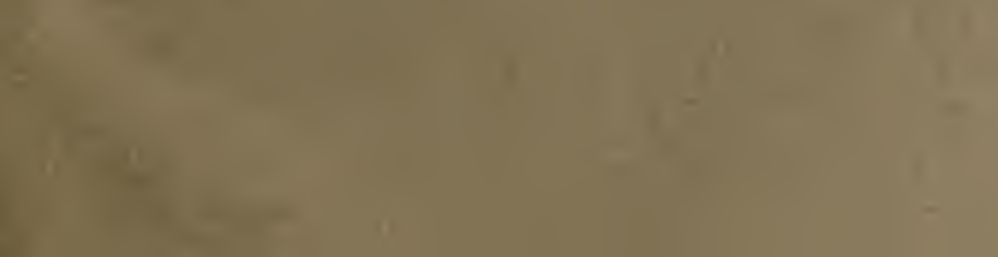


RETURN TO the circulation desk of any University of California Library

or to the

NORTHERN REGIONAL LIBRARY FACILITY

Bldg. 400, Richmond Field Station

University of California

Richmond, CA 94804-4698

ALL BOOKS MAY BE RECALLED AFTER 7 DAYS 2-month loans may be renewed by calling (510) 642-6753

1-year loans may be recharged by bringing books to NRLF

Renewals and recharges may be made 4 days prior to due date

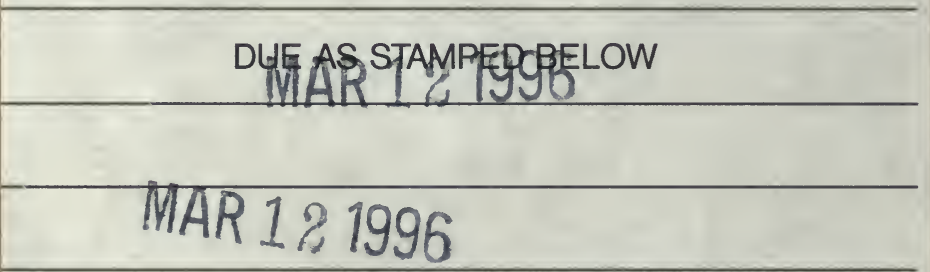

APR 292003 


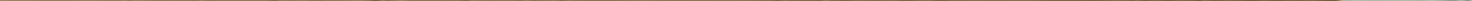

